\title{
THE JUSTIFICATION OF SNACK TECHNOLOGY WITH USING MEAT DRIED SEMI-FINISHED PRODUCT
}

\author{
Y. Matsuk, I. Marchenko, \\ Oles Honchar Dnipro National University \\ V. Pasichnyi, A. Marinin \\ National University of Food Technologies
}

\begin{tabular}{|c|c|}
\hline Key words: & ABSTRACT \\
\hline $\begin{array}{l}\text { Snack } \\
\text { Meat dried semi-finished } \\
\text { product } \\
\text { Snack technology } \\
\text { Nutritional value } \\
\text { Snack products }\end{array}$ & $\begin{array}{l}\text { The purposes of the researches are developing of technolo- } \\
\text { gy of snacks with using meat dried semi-finished product, de- } \\
\text { termining the physical and chemical properties and nutritional } \\
\text { value of finished products, determining the prospects for the } \\
\text { use of this product. The object of the researches is technology of } \\
\text { snack products with using meat dried semi-finished product. }\end{array}$ \\
\hline $\begin{array}{l}\quad \text { Article history: } \\
\text { Received 13.09.2018 } \\
\text { Received in revised form } \\
04.10 .2018 \\
\text { Accepted } 24.10 .2018\end{array}$ & $\begin{array}{l}\text { During the study, organoleptic, physico-chemical and } \\
\text { computational methods were used. } \\
\text { The technology of production of snacks using meat dried } \\
\text { semi-finished product was developed by us and the physical } \\
\text { and chemical parameters of quality of finished products }\end{array}$ \\
\hline $\begin{array}{l}\text { Corresponding author: } \\
\text { Y. Matsuk } \\
\text { E-mail: } \\
\text { npnuht@ukr.net }\end{array}$ & $\begin{array}{l}\text { (moisture content, protein, fat, carbohydrates, sucrose, ash, } \\
\text { salt, } \mathrm{pH} \text {, water absorption) were determined. The moisture } \\
\text { content of the developed products is less than the control } \\
\text { sample by } 0.5 \ldots 1 \% \text {, the protein content is less than the con- } \\
\text { trol sample by } 8.8 \ldots 9.5 \% \text {, the tightness of the finished } \\
\text { products is lower by } 4.9-8.6 \% \text {, the salt content does not } \\
\text { exceed acceptable standards. The energy value of these } \\
\text { products was calculated. The expediency of using meat dried } \\
\text { semi-finished product in snack technology was proved. } \\
\text { These products can be considered as full-fledged meal and } \\
\text { as products with high protein content. Researches show that } \\
\text { snacks with using meat dried semi-finished product can be } \\
\text { recommended for manufacturing in food industry. }\end{array}$ \\
\hline
\end{tabular}

DOI: $10.24263 / 2225-2924-2018-24-5-23$

\section{ОБґРУНТУВАННЯ ТЕХНОЛОГІЇ СНЕКІВ 3 ВИКОРИСТАННЯМ М'ЯСНОГО СУШЕНОГО НАПІВФАБРИКАТУ}

\author{
Ю.А. Мацук, І.М. Марченко \\ Дніпровський національний університет імені Олеся Гончара \\ B.М. Пасічний, А.І. Маринін \\ Національний університет харчових технологій
}

У статті розроблено технології снеків із використанням м'ясного сушеного напівфабрикату, визначено фізико-хімічні властивості та харчову иін- 
ність готових виробів, а також перспективи використання продукиії. Об'єктом дослідження була технологія снекових виробів із використанням м'ясного сушеного напівфабрикату.

Під час проведення дослідження були застосовані органолептичні, фiзико-хімічні та розрахункові методи.

Розроблена технологія виробництва снеків із використанням м'ясного сушеного напівфабрикату, визначені фізико-хімічні показники якості готових виробів (вміст вологи, білка, жиру, вуглеводів, сахарози, золи, солі, рH, намочуваність). Вміст вологи розроблених виробів є меншим за контрольний зразок на 0,5 .. 1\%, вміст білка більший на 8,8...9,5\%, намочуваність готових виробів менша на 4,9..8,6\%, вміст солі не перевищує допустимі норми. Розрахована енергетична иінність розроблених виробів. Доведена доцільність використання МСН у технологї снеків. Вироби можуть розглядатися як повночінний прийом їжі, а також продукиія з високим вмістом білка. Проведені дослідження показують, щьо снеки з використанням м'ясного сушеного напівфабрикату можуть бути рекомендованими для виготовлення на харчових виробництвах.

Ключові слова: снек, м'ясний сушений напівфабрикат, технологія снеків, харчова иінність, снекова продукція.

Постановка проблеми. На нинішньому етапі розвитку суспільства спостерігається порушення структури харчування, зумовлене зміною ритму життя і зниженням споживання біологічно цінних компонентів харчування. Прискорений темп життя сучасної людини змушує ії харчуватися «на ходу».

Слід зазначити, що снеки (від англійського слова snack - легка закуска) ідеально підходять для вирішення цієї проблеми. Це доступні натуральні сухі продукти, готові до вживання і розфасовані в індивідуальну упаковку, що дає змогу застосовувати їх у будь-якому місці і в будь-яких умовах [1].

Загальновідомо, що виробництво снеків - це доволі молода галузь харчової промисловості України, однак за останні роки ця продукція стала популярною серед споживачів. На світовому ринку продуктів харчування снеки користуються величезною популярністю. Найбільша кількість снеків вживається у Великій Британії і в США [2]. Проте вживання снекової продукції, вирішуючи проблему дефіциту часу, не дає можливості отримувати достатньою мірою необхідні поживні й мінеральні речовини.

Проведені дослідження вітчизняного ринку снекових виробів показують, що продукція, яка б містила достатню кількість усіх нутрієнтів та могла б замінити повноцінний прийом їжі, не має широкого асортименту [3; 4]. Тому розширення виробництва снеків має соціальний ефект, направлений на створення повноцінних за біологічною цінністю продуктів.

Аналіз останніх досліджень і публікацій. Аналіз наукових досліджень вітчизняних і зарубіжних учених (В.А. Терлецької, Л.В. Молоканової В.Г. Гарбуза, О.І. Гащук, В.М. Пасічного, О.З. Попадич, Т.М. Гіро, Л.С. Кудряшова, П.В. Лушнікова, І.А. Рогова, Б.А. Рскелдієва, Я.М. Узакова та ін.) підтвердив 
важливість та актуальність проблем, порушених у цій статті. Так, з метою покращення технологічних характеристик сировини та підвищення споживчих властивостей готових виробів пропонується використання нетрадиційного поєднання білоквмісної сировини [5]. Тож створення привабливих для споживача i доступних за ціною продуктів $\epsilon$ одним із основних трендів сучасного ринку харчових продуктів.

Вітчизняними вченими I.М. Зінченко, Ю.А. Ястребою та В.А. Терлецькою запропоновано виготовлення харчових концентратів та збагачувачів з використанням їстівних грибів [6;7].

Відомі технології виробництва снеків з м'ясної сировини з використанням текстуроутворюючих наповнювачів [8], а також дослідження, присвячені розробці снеків 3 деструктурованого м'яса, що за органолептичними властивостями є аналогічною продуктам 3 в'яленого м'яса [9]. Н.Я. Орловою та Ю.В. Дяковою досліджено перспективи використання висушених баклажанів у виробництві снеків [10].

Важливим питанням також залишається вибір систем пакування продукції $з$ комбінованим складом сировини та можливість подовження термінів іiї зберігання [11; 12].

Отже, актуальним і перспективним завданням є дослідження, спрямовані на обгрунтування технології снеків 3 використанням м'ясного сушеного напівфабрикату, раціональне використання сировинних ресурсів і створення на їх основі продуктів харчування підвищеної біологічної цінності з науково обгрунтованими термінами зберігання.

Мета дослідження: визначення перспектив та обгрунтування можливості використанням м'ясного сушеного напівфабрикату $(\mathrm{MCH})$ в технології снеків.

Для досягнення поставленої мети вирішувалися такі завдання: дослідити можливість використання МСН в рецептурі снеків; обгрунтувати раціональний склад рецептури; вивчити органолептичні та фізико-хімічні, властивості розроблених виробів.

Викладення основних результатів дослідження. До снекової продукції сьогодні відносяться не тільки продукти харчування, які не рекомендуються для частого вживання в їжу. На міжнародному ринку снеків для вгамування легкого голоду позиціонуються і корисні для здоров'я продукти.

3 огляду на це предметом дослідження були обрані снеки у вигляді хлібців 3 додаванням м'ясного сушеного напівфабрикату, отриманого методом конвективного сушіння. Вивчалась можливість заміни пшеничного борошна на $\mathrm{MCH}$ у складі рецептури снеків. Частка борошна в основній рецептурі замінювалась 15\% МСН (з м'яса птиці, свинини та яловичини ). Інші складові рецептури (вода, олія соняшникова, сіль) залишались незмінними.

Технологія виготовлення снеків 3 використанням МСН включає такі технологічні етапи: підготовка сировини, змішування компонентів, вимішування тіста, отримання тістового напівфабрикату, вистоювання тістового напівфабрикату, формування тістових заготовок, випікання, охолодження готових виробів. Технологічну схему виготовлення снеків наведено на рисунку. 


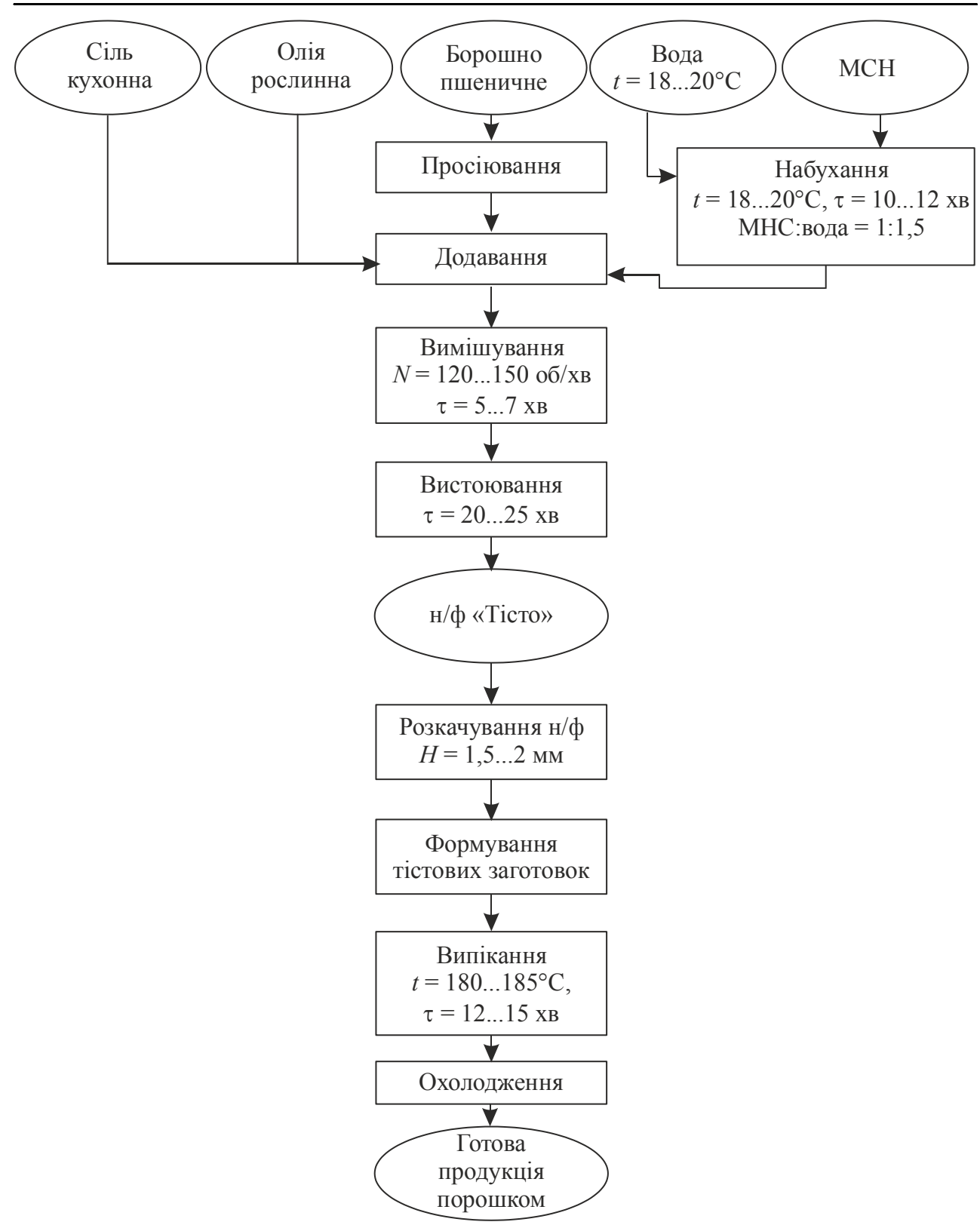

Рис. Технологічна схема виготовлення снеків із додаванням МСН

Попередньо просіяне борошно, МСН, воду, рослинну олію та сіль з'єднують у ємності. Далі суміш перемішують до однорідної консистенції та вимішують отримане тісто протягом 5 хвилин. Тісто залишають для відстоювання (20 хвилин). Після цього тісто розкатують у пласт товщиною $1,5 \ldots 2$ мм та отримують заготовки заданої форми. Тістові заготовки випікають у печі протягом $12 . .15$ хвилин за температури $180^{\circ} \mathrm{C}$. 
Відповідно до ДСТУ 2903:2005 «Харчові концентрати. Сухі сніданки» були визначені органолептичні та фізико-хімічні показники якості готових виробів.

Загальновідомо, що сенсорні показники продуктів (зовнішній вигляд, смак, запах, колір і структура) мають першорядне значення для споживача та формують загальну уяву про якість продукту. Тому в процесі досліджень були визначені органолептичні показники якості готових виробів.

Результати дегустаційної оцінки дають можливість стверджувати, що отримані зразки продуктів характеризувалися гармонійним збалансованим за вмістом інгредієнтів смаком, з приємним кольором та структурою при внесенні $\mathrm{MCH} 15 \%$. Оскільки додавання МСН у меншій кількості не має позитивного впливу на органолептичні показники якості готових виробів, тому що відсутній м'ясний присмак відповідного виду $\mathrm{MCH}$, а також не досягаються оптимальні співвідношення нутрієнтів у готовому виробі.

Враховуючи специфіку МСН, було проведене вивчення впливу його вмісту в рецептурах на хімічний склад, технологічні властивості напівфабрикатів. Результати досліджень фізико-хімічних показників розроблених снеків представлені в таблиці.

\section{Таблиця. Фізико-хімічні показники снеків 3 додаванням МСН}

\begin{tabular}{|c|c|c|c|c|}
\hline \multirow{2}{*}{ Показники } & \multirow{2}{*}{ Контроль (без } & \multicolumn{3}{|c|}{ МСН, 15\% } \\
\cline { 3 - 5 } & МСН) & 3 м'яса птиці & 3 свинини & 3 яловичини \\
\hline Вміст вологи, \% & $6,9 \pm 0,15$ & $5,9 \pm 0,14$ & $6,1 \pm 0,12$ & $6,4 \pm 0,15$ \\
\hline Вміст білка, \% & $10,2 \pm 0,25$ & $19,2 \pm 0,51$ & $19 \pm 0,46$ & $19,7 \pm 0,38$ \\
\hline Вміст жиру, \% & $15,2 \pm 0,38$ & $19,6 \pm 0,50$ & $20,4 \pm 0,28$ & $19,9 \pm 0,42$ \\
\hline Вміст вуглеводів, \% : & $66,8 \pm 1,13$ & $54,1 \pm 1,15$ & $53,2 \pm 1,14$ & $52,8 \pm 1,13$ \\
\hline $\begin{array}{c}\text { У тому числі вміст } \\
\text { сахарози, \% }\end{array}$ & $1,1 \pm 0,01$ & $0,83 \pm 0,01$ & $0,86 \pm 0,01$ & $0,77 \pm 0,01$ \\
\hline Вміст золи, \% & $0,9 \pm 0,02$ & $1,2 \pm 0,01$ & $1,25 \pm 0,02$ & $1,2 \pm 0,03$ \\
\hline Енергетичнацінність, кДж & 1861,0 & 1964,8 & 1976,5 & 1962,7 \\
\hline рН & $6,5 \pm 0,15$ & $5,9 \pm 0,15$ & $6,2 \pm 0,15$ & $5,1 \pm 0,15$ \\
\hline Намочуваність, \% & 138,7 & 131,9 & 130,1 & 133,8 \\
\hline
\end{tabular}

Аналізуючи отримані дані, можна стверджувати, що додавання МСН до складу снекових виробів зменшує показник вологості. Це сприятиме кращому збереженню властивостей під час зберігання продукції. Вміст сахарози у виробах менший, ніж у контрольному зразку, тому що $\mathrm{MCH}$ замінює відповідну частку борошна. Показник намочуваності у виробів менший, ніж у зразку без додавання МСН. Це свідчить про те, що експериментальні зразки порівняно 3 контролем мають більш щільну структуру, меншу пористість, а також крихкість. Така властивість важлива під час зберігання й транспортування готових виробів. Вміст солі $(1,31 \ldots 1,52 \%)$ у всіх зразків відповідає чинним вимогам до якості.

Узагальнюючи вищевикладене, можна стверджувати, що додавання $\mathrm{MCH}$ до складу снеків (хлібців) покращує фізико-хімічні властивості готових виробів, оптимізує нутрієнтний склад і підвищує енергетичну цінність продукції.

Тож продукція може бути рекомендована для споживання як повноцінний прийом їжі. Розроблені снеки можуть бути найбільш корисним та зручним для використання продуктом серед таких соціальних груп населення, як лю- 
ди, що займаються туризмом, активним відпочинком в умовах, коли приготування їжі є незручним, а також для військових як альтернатива продуктам, що є складовими їхнього раціону.

\section{Висновки}

Отже, результати проведених досліджень дали змогу обгрунтувати можливість ефективного використання МСН у технології снекових виробів, установити раціональну масову частку його внесення в комбіновані системи. Доведено, що МСН збагачує продукти нутрієнтами, які наближають продукт до продукту зі збалансованим складом.

При раціональному підборі компонентів, що входять до складу снекових виробів, можуть бути досягнуті високі органолептичні та функціонально-технологічні показники готової продукції.

Виробництво будь-яких нових видів харчових продуктів, заснованих на введенні в рецептуру нових інгредієнтів, вимагає ретельного дослідження строків їх зберігання. Враховуючи специфіку МСН, планується вивчення його внесення на термін зберігання снекових виробів.

\section{Лiтература}

1. Молоканова Л.В., Орешина О.О. Хімічний склад вітчизняних м'ясних снеків. Науковий вісник PUET: Technical Sciences. 2015. № 1(52). С. 119-124.

2. Синьоок I.В., Теличкун В.I. Розширення асортименту та удосконалення обладнання для виробництва снеків. Технічні науки: стан, досягнення і перспективи розвитку м'ясної, олієжирової та молочної галузей: програма і матеріали другої міжнародної науковотехнічної конференції, 20-21 березня 2013 р. - Київ: НУХТ, 2013. С. 71-72.

3. Страшинська Л.В., Ніколаєнко І.В. Маркетингові аспекти розвитку ринку снеків в Україні [Текст]. НУХТ. Київ. 2017. С. 75-84.

4. Свсейцева О.С., Ющенко А.В. Аналіз ринку снекової продукції України. Вісник Київського національного університету технологій та дизайну. 2012. № 6(68). С. 357-362.

5. Пасичный В.Н. Проблема белка или проблема качества пищи. Мясной бизнес. 2004. № 2. Ч. 1. С. $12-18$.

6. Зінченко І.М., Терлецька В.А. Харчконцентрати на основі їстівних грибів. Науковотехнічні розробки та іноваційні технологї̈. Київ: НУХТ, 2010. С. 26.

7. Пасічний В.М., Ястреба Ю.А. Обгрунтування параметрів сушіння грибів під час виробництва порошкоподібного напівфабрикату. Зб. наук. пр. / Харк. держ. ун-т. харчування та торгівлі. 2009. випуск № 2(10). С. 204-209.

8. Пасічний В.М., Желуденко В.Ю., Бомко І.В. Виробництво в'ялених м'ясних снеків 3 використанням текстуроутворюючих наповнювачів. Наукове здобуття молоді у вирішенні актуальних проблем виробництва та переробки сировини, стандартизації і безпеки продовольства: програма та матеріали другої міжнародної науково практичної конференції, 19-20 квітня 2012 року, Київ: НУБІП, 2012. С. 234-236.

9. Орешина О.О., Молоканова Л.В. Вплив виду звязувальних компонентів на якість снеків 3 деструктурованого мяса баранини. Праці Таврійського державного агротехнологічного університету. 2013. Вип. 13, Т. 1. С. 155-161.

10. Дьякова Ю., Орлова Н. Безпечність баклажанових снеків. Товари і ринки. 2015. № 1. С. $175-182$.

11. Пасічний В.Н., Захандревич О. Характеристика основної м'ясної сировини та субпродуктів для виробництва ковбасних виробів вареної групи. Мясное дело. 2008. № 1. С. $39-42$.

12. Пасічний В.М., Гередчук А.М., Мороз О.О., Ястреба Ю.А. Дослідження факторів пролонгації термінів зберігання м'ясних і м'ясомістких продуктів. Наукові пращі Національного університету харчових технологій. 2015. Т. 21, № 4. С. $224-230$. 